\title{
Land Valuation Systems using GIS Technology Case of Matara Urban Council Area, Sri Lanka
}

\author{
Lin Li and Pussella PGRNI \\ Wuhan University, China
}

Gunathilake MDEK, Munasinghe DS and Karadana CA
Sabaragamuwa University, Sri Lanka

lilin@whu.edu.org,pgrnip@geo.sab.ac.lk,erandakan@geo.sab.ac.lk, deepika@geo.sab.ac.lk,karadana@geo.sab.ac.lk

\begin{abstract}
Land valuation is the process of assessing the characteristics of a given piece of land based on experience and judgment. The objective of land valuation is to determine a market value or benefit value which is fundamentally determined by its location. This emphasizes the significance of spatial factors in decision making of land valuation. In order to make adequate value estimation for a land, there are many tangible and intangible land valuation factors that should be taken into account during the valuation process. A sufficient estimation can be done by analyzing a certain amount of land characteristics in an objective way. In this research project, to determine the market value of a land, it was used seven parameters namely, distance to schools, distance to roads, distance to police station, distance to railway station, distance to health facilities, land-use type and distance to government buildings. For each and every factor, the shape files were created using the 1:10,000 data which is prepared by the Survey Department of Sri Lanka. The weights which were determined by the questionnaire survey and Analytical Hierarchical Process (AHP) technique were used to categorize above maps in a GIS environment. The final results were shown a remarkable result about the values of the land. Finally, the area was divided into land value classes and categorized as very low, low, moderate, high and very high valued areas. It can be discovered that the total area is having a higher value, as the area is well equipped with infra structure facilities and other facilities. It can be concluded that this kind of model would be very much needed in the process of land valuation. Further, the study suggested that the model should be enriched with a number of parameters than this proposed model.
\end{abstract}

\section{Introduction}

Land valuation is the process of assessing the characteristics of a given piece of land. The process may be described as a carefully estimation of the worth of landed property based on experience and judgment. However, the objective of land valuation is to determine a value which is generally prefaced by terms such as market value or benefit value. Generally, the land value is the monetary value of land expressed either as a capital value or an annualized economic rent (Gyourko and Tracy, 1991). In practice, land valuation is a professional judgment and it is based on a range of information and the features on the land including the market value of the land and the buildings in the neighborhood, assessments of reconstruction costs and existing planning permissions
(Riley, 2002). In land valuation, it is a common understanding that the value and potential of a property are fundamentally determined by its location. This emphasizes the significance of spatial factors in decision making of land valuation. In the land valuation process in Sri Lanka, the valuation officer would consider a lot of external and internal factors. As external factors, the basic infra structure facilities such as presence of electricity, telephone facility and water would be considered in the process. Also the distances to other facilities such as schools, main and minor roads and financial institutions in the surrounding area play a vital role. Further, he would check the current and recent land values of surrounding areas by examining the previous and recent land transactions. These past records can be obtained from the financial institutions and 
Inland Revenue department of Sri Lanka. In this process, the valuation officer, definitely, has to get some reliable sources, unless it would lead some unexpected values for the land. After these examinations, a rough value for the land would be generated in his mind.

In practice, this manual process makes a lot of problems. Specially, this is a personal oriented method. The way of analyzing the features and giving them a value may be changed person to person. It will lead to different values for a same land by different valuation officers. Therefore, there should be a proper concept or a mechanism in valuing a land. This research gives a reasonable solution for this problem by introducing a land valuation model using Geographical Information Systems (GIS) technology. A GIS is undoubtedly useful in this decision making. A sufficient estimation can be done by analyzing a certain amount of land characteristics in an objective way. In order to make adequate value estimation for a land, there are many tangible and intangible land valuation factors that should be taken into account during the valuation process.

As a solution to overcome the problems related to this land valuation process, this project work will address following objectives in modeling the land valuation.

1. Identifying the internal and external factors to determine the value of a land

2. Recognizing the individual influences of different factors for the value of a land

3. Generating the model to indicate the land values

4. Classifying the study area into different zones such as high valuable areas, moderate valuable areas and low valuable areas

\section{Literature Review}

The process of valuation can be described as the carefully considered estimate of worth of landed property based on experience and judgment by identifying and assessing the characteristics of a given land (Dubin, 1988). The main and specific objective of the process of valuation is, however, to determine "value" (Dubin, 1988). The method of valuation that is widely adopted is that of open market value using the comparative method. This technique requires adequate records of transactions (Wyatt, 1997), but appraisers are often unable to gather information on comparable properties due to commercial secrecy, a lack of data, real estate tax system and ad hoc information dissemination. It is rather difficult to monitor all transactions and it is even harder to track all purchase prices. A lot of facts influence the price of a certain fixed asset (Kertscher, 2003).

The determination of a land parcel value depends on a number of physical and economic characteristics which must be taken into consideration very carefully in a land valuation procedure. Some of these characteristics are intrinsic to the land; others are external or environmental factors. These factors can be determined in an objective way but there is always a certain degree of subjectivity that is difficult to measure in the valuation process (Yomralioglu, 1993). Location influences on property value are widely regarded as the most important, yet their incorporation into valuation methodology is often implicit. The number of land valuation factors is uncertain. Therefore, the precise value for a land unit cannot be determined easily. To determine the significance of these factors for a land parcel, they need to be expressed mathematically so that the effect of each valuation factor can be determined for the complete land parcel (Yomralioglu, 1993). In reality, the determination of an exact value for a land parcel is almost impossible but an estimation of the asset value can be conceivable.

According to Wyatt (1995), the value of property reflects its capacity to fulfill a function. With regard to commercial property, functional qualities may include,

- Location influences (accessibility to the market place, proximity to suppliers of raw materials and important nodes such as railway stations, car parks and open spaces)

- Physical attributes (size, shape, age and condition)

- Legal factors (lease terms and restrictive covenants)

- Planning and economic factors (planning constraints, permitted use and potential for change of use). 
All these factors can be classified into two categories, such as, social factors and physical factors. For the regional factor, the most of the valuation models consider as a social factor. Economic and political factors are also coming under the social factor category. For the physical factors, most of the models consider the characteristics of the land parcel (such as area, width, depth, shape, location and terrain), the adjacent to other land use type (such as, distance to transportation facility, distance to station, distance to grocery store, and distance to public facility), environmental conditions (such as, public security, and social welfare) and land use conditions (such as, land use type and land use intensity).

The Building of the Mass Land Appraisal Method Research (Chung, 1992) adapted the following characteristics and created the model as follows.

Land Price Function: $\mathrm{P}=\mathrm{f}(\mathrm{L}, \mathrm{P}, \mathrm{T}, \mathrm{C})$,

Where $\mathrm{P}=$ Land Price, $\mathrm{L}=$ Land Characteristics, $\mathrm{P}=$ Public Facility, $\mathrm{T}=$ Public Transportation, $\mathrm{C}=$ Land Use Control

Land Appraisal Model: $\mathrm{P}=12622+369.8 \mathrm{X} 1+$ $690.6 \mathrm{X} 2-6.3 \mathrm{X} 3+6.1 \mathrm{X} 4-3.5 \mathrm{X} 5-20.1 \mathrm{X} 6+$ $50.5 \times 7-3.1 \times 8+16.9 \times 9-61.8 \times 10$

Where, X1 = Depth of the Parcel, X2 = Width of the adjacent road, X3 = Distance to bus stop, $\mathrm{X} 4=$ Distance to the nearest long distance transportation station, $\mathrm{X} 5=$ Distance to the nearest major road, $\mathrm{X} 6=$ Distance to CBD, $\mathrm{X} 7=$ The degree of land use control, $\mathrm{X} 8$ $=$ Distance to the nearest park, $\mathrm{X} 9=$ Distance to culture center, $\mathrm{X} 10=$ Distance to the nearest college or university

GIS provides a technological platform on which to base such an analysis and an initial stage is the spatial representation of property information in the form of value maps (Wyatt, 1995). GIS capabilities not only facilitate the organization and management of geographic data, but they also enable researchers to take full advantage of location information contained in these databases to support the application of spatial statistical and spatial econometric tools (Can, 1990). Due to the complexity of land valuation process, providing property owners with an easy understood explanation of how their property has been valued is a continual challenge for planners and assessors. Today GIS is able to execute all these complex tasks.

To increase the effectiveness of land valuation process, a nominal asset value-based model has been developed using GIS. The main objective in this model is to determine the asset value of a land with different land valuation factors which are formulated and spatially examined. Using GIS in a multicriteria land valuation analysis is also provides a value estimation mechanism in large scale spatial data applications. In this method rather than dealing with the real-market prices, the qualitative and quantitative characteristics of individual land properties have been examined.

Analytical Hierarchical Process (AHP) approach is preferred for weighting, because of its simplicity of the use and its higher accuracy (Nonis et al., 2007). This method was developed at the Wharton School of Business by Thomas Saaty in 1980 and it allows decision makers to model complex problems in a hierarchical structure showing the relationships of the goal, objectives (criteria), sub-objectives, and alternatives. The decision making in AHP is a continuous process which starts from analyzing the decision environment to understand and arrange the criteria into different groups and levels until evaluating the criteria. Another important aspect in this technique is that the possibility to include the uncertainties and other influencing factors in to consideration (Nonis et al., 2007).

\section{Methodology}

Matara Divisional Secretariat area was selected as the study area in this project (Figure 3.1). It has a very good potential with different types of features, land uses and, specially, rural and urban characteristics. Therefore, it would be a very good area to identify the special characteristics for a land valuation model as a pilot project. 


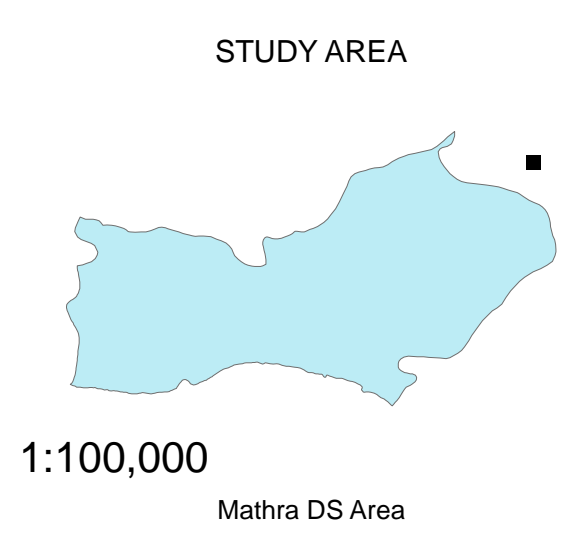

Figure 3.1: Study area

The area was covered with 1:5,000 scale representations by the Survey Department of Sri Lanka. Since then, using the digital data set, it was prepared the shape files for different features which are the land valuation parameters. These parameters were identified using the data availability and the experts' views in the field. Access to streets (Figure 3.2), Distance to educational centers (Figure 3.3), Distance to health services (Figure 3.4), Distance to police station (Figure 3.5), Access to railway (Figure 3.6), Land-use type (Figure 3.7) and Distance to government buildings (Figure 3.8) were considered as valuation parameters in this study.

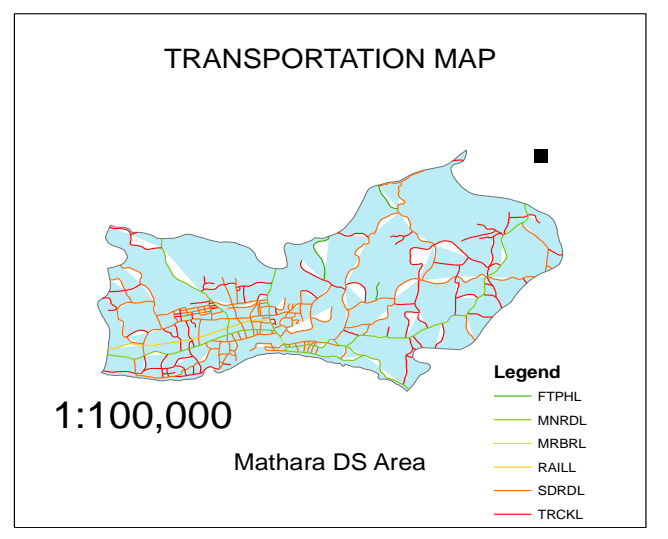

Figure 3.2: Transportation

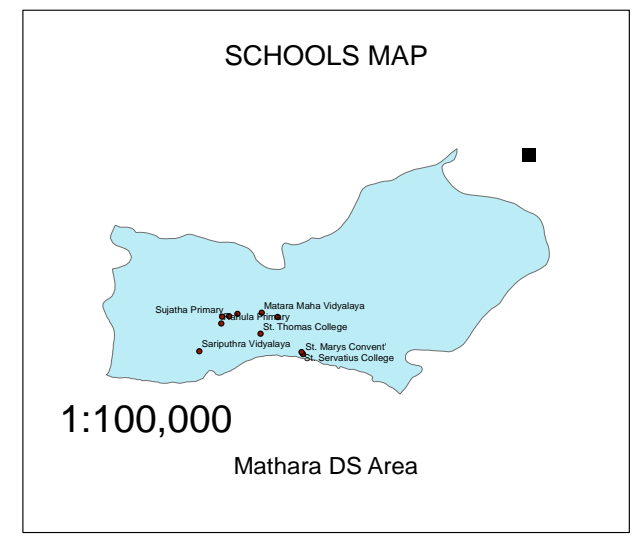

Figure 3.3: Schools

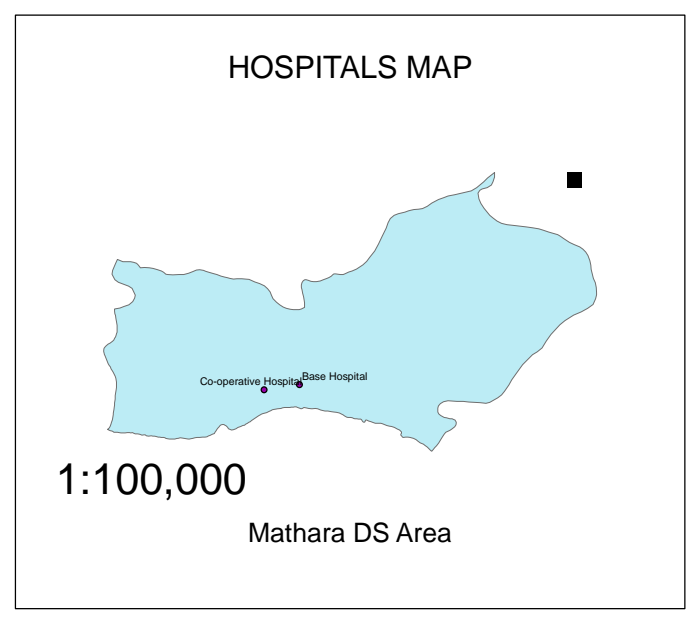

Figure 3.4: Hospitals

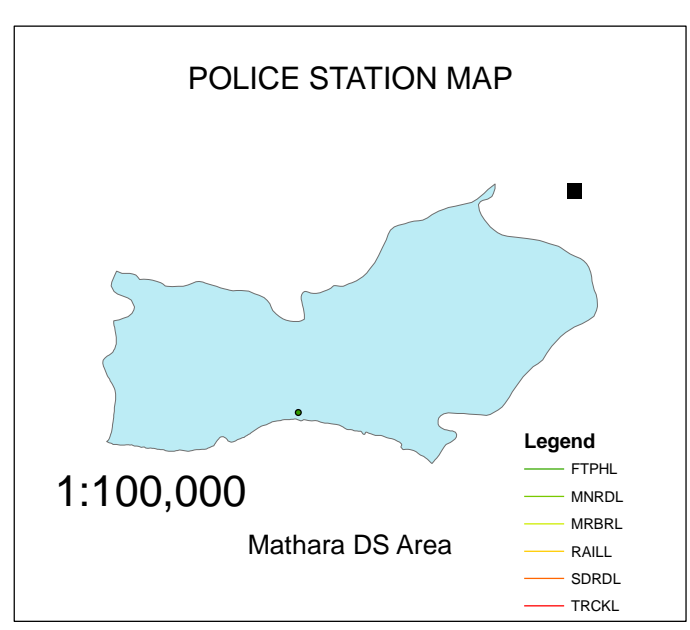

Figure 3.5: Police Stations 


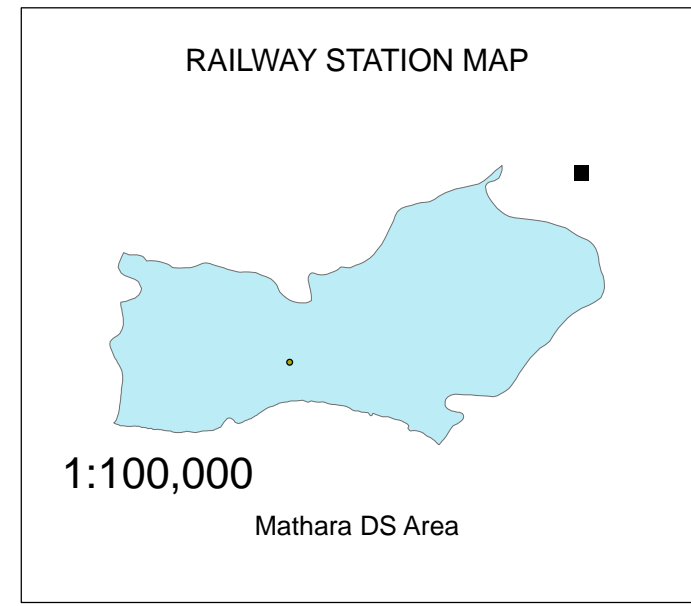

Figure 3.6: Railway Station

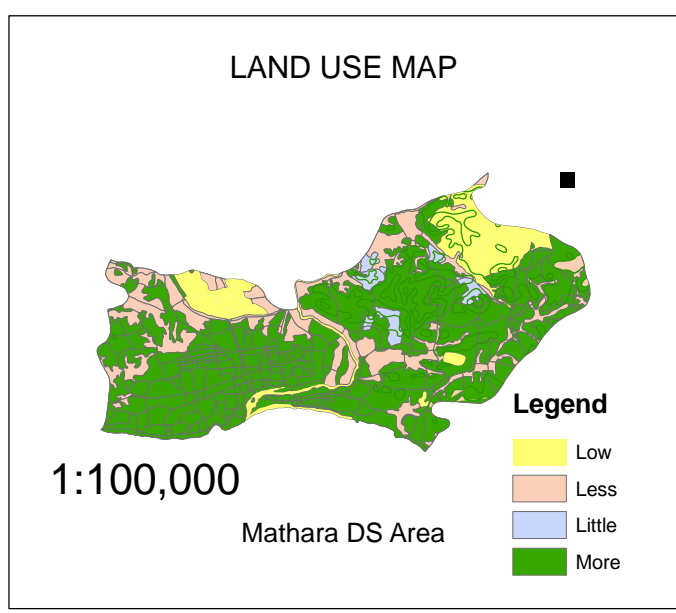

Figure 3.7: Land Use

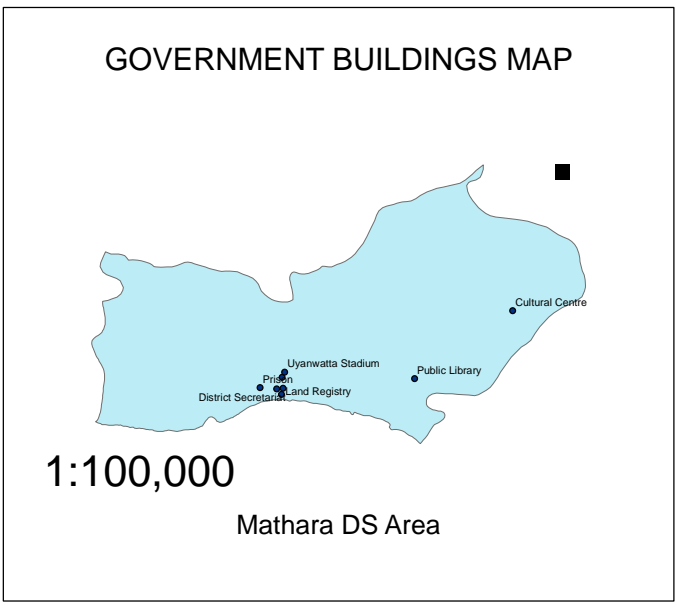

Figure 3.8: Government Buildings

\begin{tabular}{|c|c|c|}
\hline Data Layer & Factors & $\begin{array}{l}\text { Initial } \\
\text { Weights }\end{array}$ \\
\hline \multirow{5}{*}{$\begin{array}{l}\text { 1. Access } \\
\text { Transport } \\
\text { (Figure 3.9) }\end{array}$} & $<100 \mathrm{~m}$ & 05 \\
\hline & $100 m-500 m$ & 04 \\
\hline & $500 m-1000 m$ & 03 \\
\hline & $1000 m-2000 m$ & 02 \\
\hline & $>2000 \mathrm{~m}$ & 01 \\
\hline \multirow{5}{*}{$\begin{array}{l}\text { 2. Distance to } \\
\text { Schools (Figure } \\
\text { 3.10) }\end{array}$} & $<500 \mathrm{~m}$ & 05 \\
\hline & $500 m-1000 m$ & 04 \\
\hline & $1000 m-2000 m$ & 03 \\
\hline & $2000 m-5000 m$ & 02 \\
\hline & $>5000 \mathrm{~m}$ & 01 \\
\hline \multirow{5}{*}{$\begin{array}{l}\text { 3. Distance to } \\
\text { health services } \\
\text { (Figure 3.11) }\end{array}$} & $<1000 \mathrm{~m}$ & 05 \\
\hline & $1000 m-2000 m$ & 04 \\
\hline & $2000 \mathrm{~m}-5000 \mathrm{~m}$ & 03 \\
\hline & $\begin{array}{l}5000 \mathrm{~m} \\
10000 \mathrm{~m} \\
\end{array}$ & 02 \\
\hline & $>10000 \mathrm{~m}$ & 01 \\
\hline \multirow{5}{*}{$\begin{array}{l}\text { 4. Distance to } \\
\text { police station } \\
\text { (Figure 3.12) }\end{array}$} & $<1000 \mathrm{~m}$ & 05 \\
\hline & $1000 m-2000 m$ & 04 \\
\hline & $2000 m-5000 m$ & 03 \\
\hline & $\begin{array}{l}5000 \mathrm{~m} \\
10000 \mathrm{~m}\end{array}$ & 02 \\
\hline & $>10000 \mathrm{~m}$ & 01 \\
\hline \multirow{2}{*}{$\begin{array}{l}\text { 5. Access to } \\
\text { railway } \\
\text { (Figure 3.13) }\end{array}$} & $<500 \mathrm{~m}$ & 05 \\
\hline & $500 m-1000 m$ & 04 \\
\hline
\end{tabular}

The above data layers were initially classified as follows (Table 3.1). The initial weights were given according to the experts' views and their suggestions. 


\begin{tabular}{|c|c|c|}
\hline & $1000 m-2000 m$ & 03 \\
\hline & $2000 \mathrm{~m}-5000 \mathrm{~m}$ & 02 \\
\hline & $>5000 \mathrm{~m}$ & 01 \\
\hline \multirow[t]{4}{*}{$\begin{array}{l}\text { 6. Land-use type } \\
\text { (Figure 3.14) }\end{array}$} & $\begin{array}{l}\text { Coconut, Home } \\
\text { Garden, Rubber, } \\
\text { Built up area }\end{array}$ & 05 \\
\hline & Other & 02 \\
\hline & Paddy & 01 \\
\hline & $\begin{array}{l}\text { Forest, Tank, } \\
\text { Water area, } \\
\text { Marshy, Sandy, } \\
\text { Stream, }\end{array}$ & 00 \\
\hline
\end{tabular}

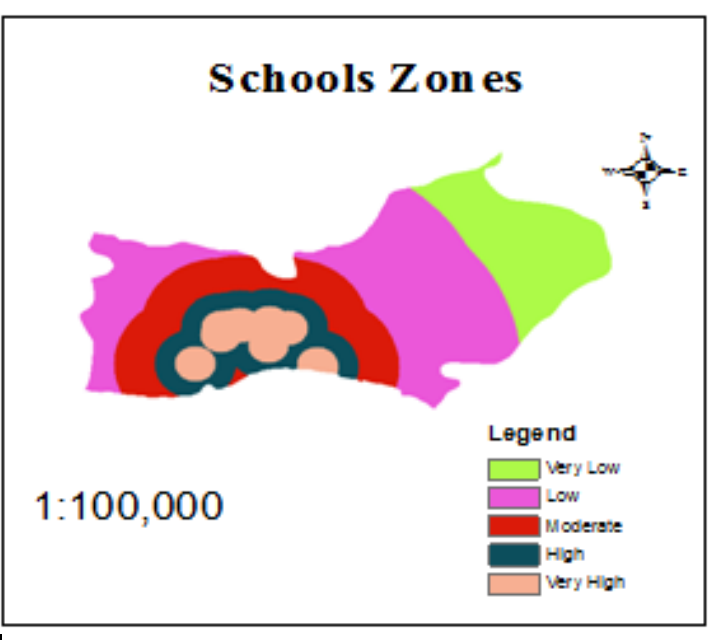

Figure 3.10: Schools Zones

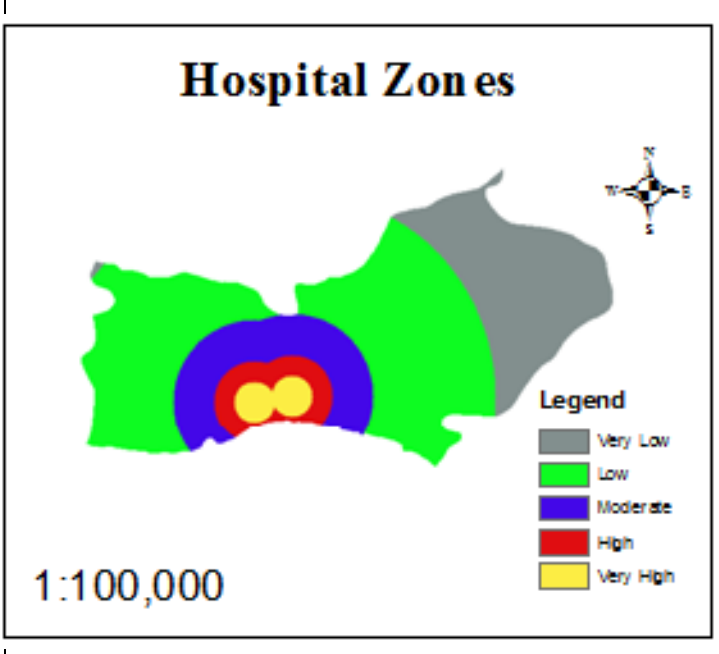

Figure 3.11: Hospitals Zones

Table 3.1: Initial Weights for the GIS Layers

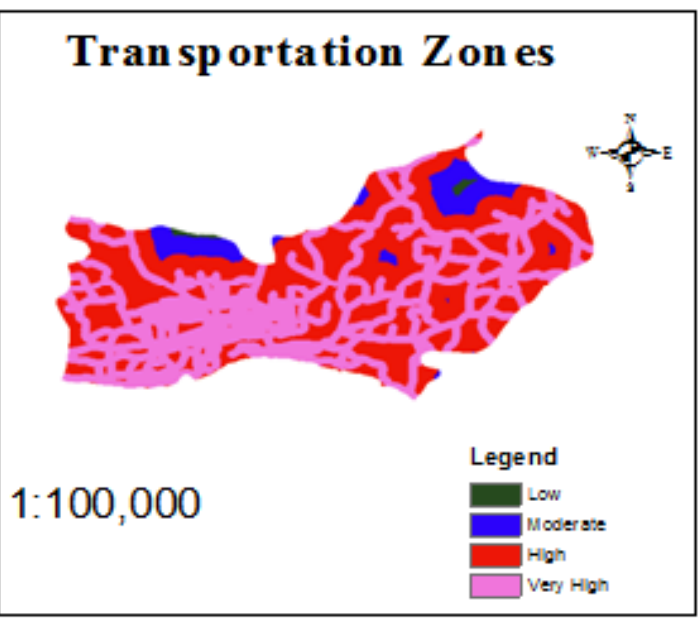

Figure 3.9: Transportation Zones

\section{Police Station Zones}

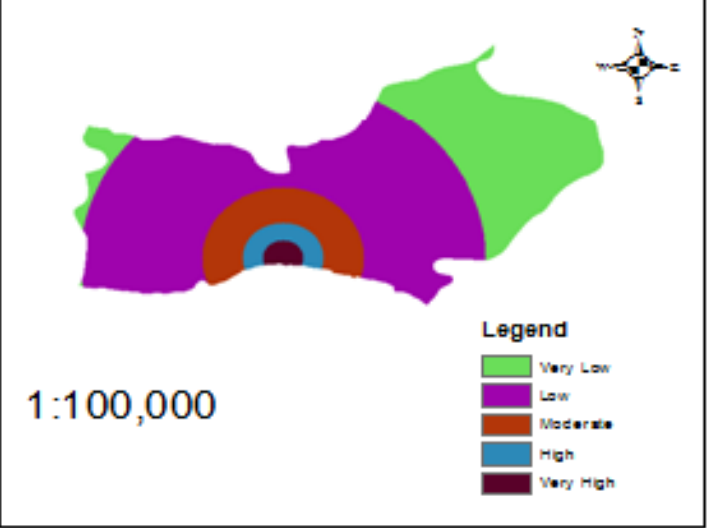

Figure 3.12: Police Station Zones 


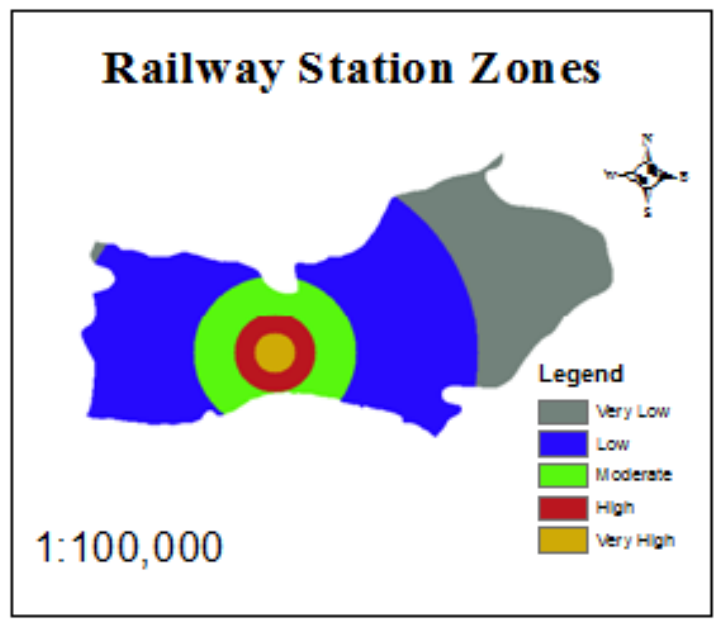

Figure 3.13: Railway Station Zones

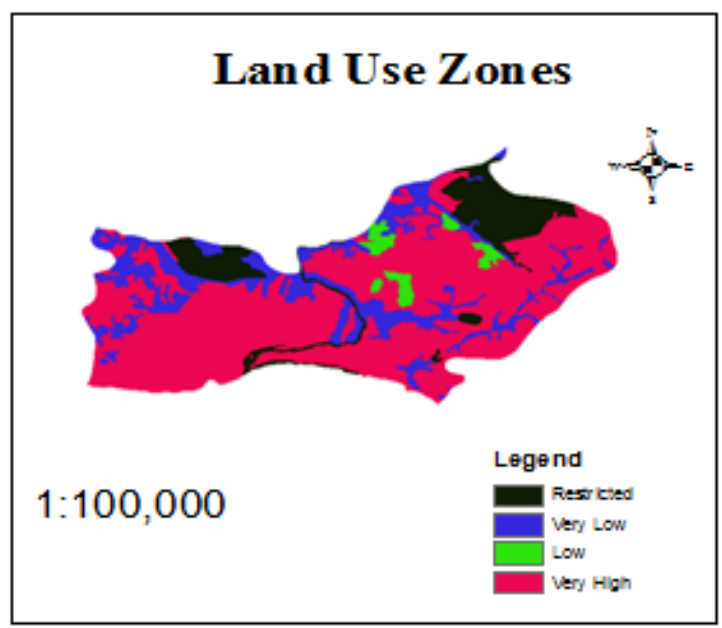

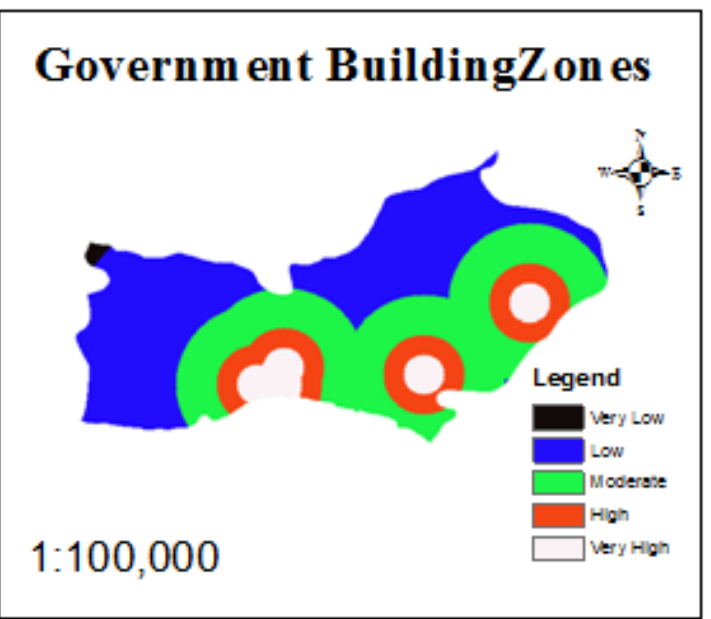

Figure 3.15: Government Building Zones

The values in the cells of pair wise comparison matrix were determined by using the rule of "the minority should obey the majority" (Manlun, 2003) (Table 3.2). In the case of comparing the criteria by experts as above, there would be having different opinions by different experts. The normalized matrix (Table 3.3) was defined using the values which were determined by dividing all the values from the sum of columns in the pair wise comparison matrix.

Figure 3.14: Land Use Zones

\begin{tabular}{|c|c|c|c|c|c|c|c|}
\hline Criteria & A & B & C & D & E & F & G \\
\hline Access to Transport (A) & 1 & 3 & 1 & 3 & 3 & 5 & 7 \\
\hline Distance to Schools (B) & $1 / 3$ & 1 & 5 & 1 & 3 & 2 & 6 \\
\hline Distance to Hospitals (C) & 1 & $1 / 5$ & 1 & 3 & 2 & 7 & 8 \\
\hline Distance to Police Stations (D) & $1 / 3$ & 1 & $1 / 3$ & 1 & 1 & 5 & 6 \\
\hline Access to Railway (E) & $1 / 3$ & $1 / 3$ & $1 / 2$ & 1 & 1 & 6 & 5 \\
\hline Land - Use Type (F) & $1 / 5$ & $1 / 2$ & $1 / 7$ & $1 / 5$ & $1 / 6$ & 1 & 2 \\
\hline Distance to Govt. Buildings (G) & $1 / 7$ & $1 / 6$ & $1 / 8$ & $1 / 6$ & $1 / 5$ & $1 / 2$ & 1 \\
\hline SUM & $\mathbf{3 . 3}$ & $\mathbf{6 . 2}$ & $\mathbf{8 . 0}$ & $\mathbf{9 . 4}$ & $\mathbf{1 0 . 4}$ & $\mathbf{2 6 . 5}$ & $\mathbf{3 5}$ \\
\hline
\end{tabular}

Table 3.2 Pair Wise Comparison Matrix

\begin{tabular}{|c|c|c|c|c|c|c|c|c|c|}
\hline Criteria & A & B & C & D & E & F & G & Sum & Final Weights \\
\hline Access to Transport (A) & 0.30 & 0.48 & 0.13 & 0.32 & 0.29 & 0.19 & 0.20 & 1.91 & $1.91 / 7=0.27$ \\
\hline Distance to Schools (B) & 0.10 & 0.16 & 0.62 & 0.11 & 0.29 & 0.08 & 0.17 & 1.53 & $1.53 / 7=0.22$ \\
\hline Distance to Hospitals (C) & 0.30 & 0.03 & 0.13 & 0.32 & 0.19 & 0.26 & 0.23 & 1.46 & $1.46 / 7=0.21$ \\
\hline Distance to Police Stations (D) & 0.10 & 0.16 & 0.04 & 0.11 & 0.09 & 0.19 & 0.17 & 0.86 & $0.86 / 7=0.12$ \\
\hline Access to Railway (E) & 0.10 & 0.05 & 0.06 & 0.11 & 0.09 & 0.23 & 0.14 & 0.78 & $0.78 / 7=0.11$ \\
\hline Land - Use Type (F) & 0.06 & 0.08 & 0.01 & 0.02 & 0.02 & 0.04 & 0.06 & 0.29 & $0.29 / 7=0.04$ \\
\hline Distance to Govt. Buildings (G) & 0.04 & 0.04 & 0.01 & 0.01 & 0.03 & 0.01 & 0.03 & 0.17 & $0.17 / 7=0.03$ \\
\hline SUM & $\mathbf{1 . 0 0}$ & $\mathbf{1 . 0 0}$ & $\mathbf{1 . 0 0}$ & $\mathbf{1 . 0 0}$ & $\mathbf{1 . 0 0}$ & $\mathbf{1 . 0 0}$ & $\mathbf{1 . 0 0}$ & $\mathbf{7 . 0 0}$ & $\mathbf{1 . 0 0}$ \\
\hline
\end{tabular}

Table 3.3 Normalized Matrix 
Model Builder is a tool for creating and managing automated and self documenting spatial models. It is providing a common tool with ArcGIS software and thus it can be applied for other models which do not required the spatial analyst functions. Model builder enables users to create process flow diagrams and scenarios to automate the modeling process. Users can easily change the data sets which are used by the model, modify the influence of each data set in the model, perform complex analysis functions and generate maps that illustrate the results of the analysis. The advantage of this model is the availability of modifying tools to add data layers and to define suitable criteria for the analysis. Further, the model gives some opportunities to the user or analyst to alter the weights in the model for different areas and for different environmental conditions. The weighted overlay tool allows actions to perform the calculation process of several raster layers, overlaying them, multiplying them by their relative weights and summing up them together to produce the land valuation map (Figure 3.16).

The final results map was classified into five main classes such as Restricted areas, Very Low valued areas, Low valued areas, Moderately valued areas, High valued areas and Very high valued areas (Figure 4.1). The result gives a better solution to the valuation officers to take some decisions in land valuation without going to the field verification process.

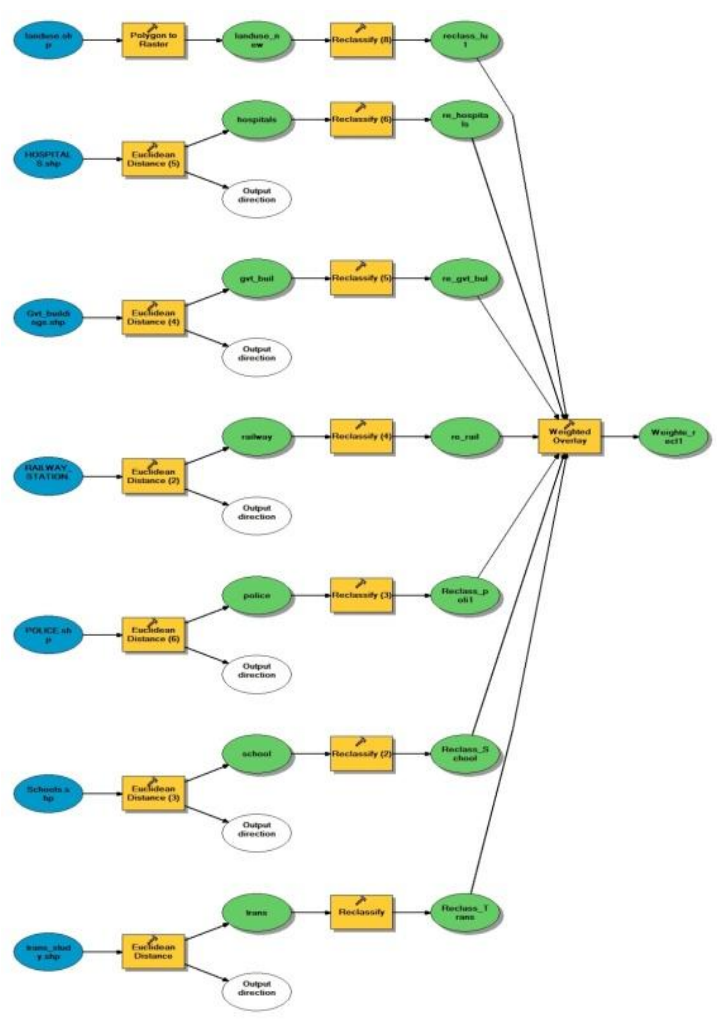

Figure 3.16: GIS model

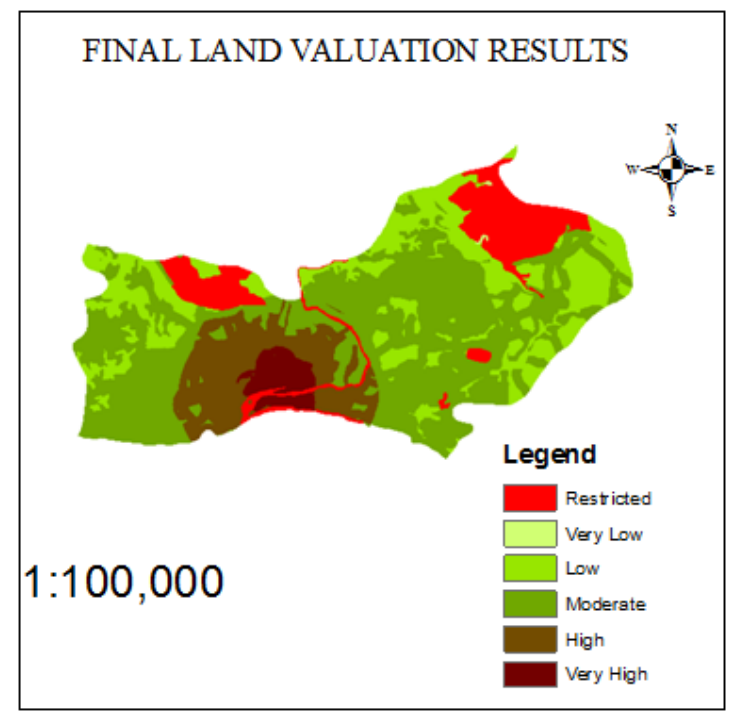

Figure 4.1: Final Land Valuation Results

According to the results from the model, the total area can be classified as follows on the area covered by different valuation ranks (Table 4.2). 
Table 4.2: Different zones and areas

\begin{tabular}{|l|c|c|}
\hline \multicolumn{1}{|c|}{ Rank } & $\begin{array}{c}\text { Total Area } \\
\text { covered } \\
\left(\mathbf{k m}^{\mathbf{2}}\right)\end{array}$ & $\begin{array}{c}\text { Percentage } \\
(\mathbf{\%})\end{array}$ \\
\hline Restricted & 6.62 & 13.45 \\
\hline Very low valued & 0.04 & 0.09 \\
\hline Low valued & 11.63 & 23.60 \\
\hline Moderately valued & 22.54 & 45.73 \\
\hline High valued & 6.69 & 13.60 \\
\hline Very high valued & 1.75 & 3.53 \\
\hline SUM & $\mathbf{4 9 . 2 7}$ & \\
\hline
\end{tabular}

The final results show that the study area is having more lands as high or moderately high areas from the total area. The restricted areas are there as water areas and forest areas. Therefore, in the case of valuation a land, the valuer must ignore those areas during his process. Further, it was revealed that most of the areas, except the restricted area, are having a higher values, since the area is well connected with a lot of infra structure and other facilities. Further, it can be seen that the zones which are much closed to the center of the main town are having very high values as the land value, because of the abundance of facilities such as schools, main roads and commercial buildings.

\section{Discussion and Recommendations}

The model gives a very good result for the land valuation process which is currently conducting using the manual method. Since the manual method is very subjective to the person who values a land, it gives a lot of problems in the field. Major problem of this current method is there are so many differences between the values which have been conducted by different people. While one is focusing about the physical facilities mostly, at the same time another person would give the more concentration on the leisure and the peacefulness in the area. Actually, it is very difficult to value a land by considering all these factors. Therefore, there should be a reasonable methodology and a common methodology for land valuation which is a combination of all the parameters. Initially, the proposed model can be used to have an idea about the area and it would be very helpful for the valuers.

Since the model is a combination of a number of parameters which are used by the process, it is considering about the individual influences of different parameters. Therefore, this kind of model can be recommended for the land valuation process. After having a good understanding about the area initially, the valuer can go to the specific land parcel and he can verify about the physical properties on the land and include them too to the model. Finally, he can give the final value of the land by considering all the factors. Another advantage of this model is, if the land is a bear land, without going to the field, he can suggest the value of the land. Further, it can be recommended to the model that all the parameters must be considered to the model, since the proposed model is only worrying about seven factors. In this model, due to the less time availability, it was considered only seven parameters. But it can be included the parameters such as the locations of banks, commercial buildings, private medical centers, private and international education centers, private roads, electricity and telephone facilities to enrich the model. Then it would be a very good model to the land valuation process. 


\section{References}

Can, A (1990), The measurement of neighborhood dynamics in urban house prices. Economic Geography 66(3), 254-272.

Chung M. Y., (1992), Research of Building Mass Appraisal Approach, Doctoral Dissertation, Dept. of Land Policy, National Cheng Chi University, Taiwan

Dubin, R (1988), Estimation of regression coefficients in the presence of spatially auto correlated error terms. Review of Economics and Statistics 70, 466-474.

Gyourko, J. and J. Tracy (1991), 'The structure of local public finance and the quality of life', Journal of Political Economy, 99, 774-806.

Kertscher, D., (2003), The German Digital Purchase Price Collection,--Maintenance, Use, Results, FIG Working Week 2003, Germany

Manlun, Y., (2003), Suitability Analysis of urban green space system based on GIS , Master Degree Thesis ,International Institute for Geo- information sciences and earth observation, Netherlands.

Nonis, C. N., Varghese, K. and Suresh, K.S., (2007), Investigation Of An AHP Based Multi Criteria Weighting Scheme for GIS Routing of cross country pipe line projects.24th International symposium on Automation \& Robotics in Construction(ISARC 2007), Madras.

Riley, C. (2002), Comments on Mills and Evans, proceedings of seminar on Land Use Regulation, Lincoln Institute for Land Policy, Cambridge Mass.

Saaty, T.L., (1980), The Analytic Hierarchy Process. McGraw-Hill, New York, 20-25.

Wyatt, P.J., (1995), Using a Geographical Information System for Property Valuation, Journal of Property Valuation \& Investment, Vol. 14, No. 1, 67-79.

Wyatt, P.J., (1997), The Development of a GIS-Based Property Information Sysyem for Real Estate Valuation, International Journal of Geographical Information Systems, Vol. 11, No. 5, 435-450.

Yomralioglu, T., (1993), The Investigation of a Value-based Urban Land Readjustment Model and its Implementation Using Geographical Information Systems, PhD. Thesis, Department of Surveying University of Newcastle upon Tyne, UK 